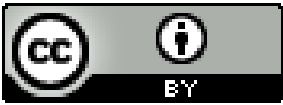

\title{
DE ORATURA E DANÇA: OXUM NA OBRA OMO-OBA: HISTÓRIAS DE PRINCESAS E NO ESPETÁCULO BRÁFRICA
}

\author{
Leandro Passos ${ }^{1}$ \\ Luana Passos ${ }^{2}$
}

\author{
Edinaldo da Silva Nascimento ${ }^{3}$
}

\begin{abstract}
Resumo: Este artigo tem por objetivo analisar, a partir do rito, do mito e da simbologia do orixá Oxum, o conto "Oxum e seus mistérios", inserido na obra Omo-Oba: histórias de princesas (2009) da escritora negra Kiusam de Oliveira, e o espetáculo BrÁfrica (2014), contemplado pelo edital de fomento Nelson Seixas da Secretária de Cultura de São José do Rio Preto, interior de São Paulo. Para fundamentar as análises, serão tomados os estudos de Girotto (1999), Prandi (2001) e Fonseca (2003) sobre religião africana e afro-brasileira; os de Ford (1999) no que diz respeito ao mito africano; os de Mata (2001) e de Rosário (2001), no que se referem à oratura africana; e os de Paiva (2009) e de Ferreira (2019) com suas contribuições acerca da dança africana e afro-brasileira. Os estudos de Jenny (1979) e de Hutcheon (1985) fundamentarão os de intertextualidade.
\end{abstract}

Palavras-chave: dança contemporânea; conto afro-brasileiro; mito iorubá; intertextualidade; identidade negra.

\section{FROM ORALITY AND DANCE: OXUM IN THE WORK OMO-OBA: HISTÓRIAS DE PRINCESAS AND IN THE SPECTACLE BRÁFRICA}

Abstract: This article aims to analyze, from the rite, the myth and symbology of the Oxum
orixá, the tale "Oxum e seus mistérios", inserted in the work Omo-Oba: histórias de princesas

\footnotetext{
${ }^{1}$ Realiza estágio pós-doutoral em Letras pela UNESP-IBILCE/SJRP (2018-2020). Doutor em Letras pela UNESP-IBILCE-SJRP. Mestre em Estudos Literários pela UNESP-FCL de Araraquara e graduação em Letras pela UNESP-IBILCE/SJRP. É Professor do EBTT de Português do IFMS Três Lagoas. Integrante e Pesquisador do Grupo de Pesquisa Gênero e raça - UNESP/IBILCE. Sócio da ABPN - Associação Brasileira de Pesquisadores Negros. E-mail: leandro.passos@ifms.edu.br

2 Mestra em Estudos Linguísticos, área de Análise Linguística (Oralidade e Letramento) pela UNESP/IBILCE/SJRP. Graduação em Pedagogia pela mesma Instituição. Vice coordenadora do NUPE Núcleo Negro da UNESP para Pesquisa e Extensão. Professora da Secretária de Educação de S. J. Rio Preto/SP. Integrante e Pesquisadora do Grupo de Pesquisa Gênero e raça - UNESP/IBILCE. E-mail: passos1uz@yahoo.com.br
}

\footnotetext{
${ }^{3}$ Aluno regular e bolsista PIBAP (Programa Institucional de Bolsas aos Alunos de Pós-graduação) de Mestrado em Educação na Linha de Currículo, Formação Docente e Diversidade da UEMS - Unidade de Paranaíba. Possui graduação em Licenciatura em Pedagogia pela UNESP/IBILCE-SJRP (2015). Sócio da ABPN - Associação Brasileira de Pesquisadores Negros. E-mail: e.edinaldo@yahoo.com.br
} 
(2009) of the black writer Kiusam de Oliveira, and the spectacle BrAfrica (2014), which was contemplated by the Nelson Seixas edict of the Culture Secretary of São José do Rio Preto, in the interior of São Paulo. Girotto (1999), Prandi (2001) and Fonseca (2003) on African and Afro-Brazilian religion will be taken as a basis for the analysis; those of Ford (1999) with respect to the African myth; those of Mata (2001) and of Rosario (2001), in what refers to African orality; and those of Paiva (2009) and Ferreira (2019) with their contributions about African and Afro-Brazilian dance. The studies of Jenny (1979) and Hutcheon (1985) will substantiate those of intertextuality.

Key words: contemporary dance; afro-brazilian tale; Yoruba myth; intertextuality; black identity.

\section{DE L'ORALITE ET DE LA DANSE: OXUM DANS L'AEUVRE OMO-OBA: HISTORIAS DE PRINCESAS ET DANS LE SPECTACLE BRÁFRICA}

Résumé: Cet article vise à analyser, à partir du rite, le mythe et la symbologie d'Oxum orixá, la nouvelle "Oxum e seus mistérios", insérée dans Omo-Oba: histórias de princesas (2009) de l'écrivain noir Kiusam de Oliveira, et le spectacle BrÁfrica (2014), envisagé par l'édit de développement Nelson Seixas du Secrétaire à la Culture de São José do Rio Preto, à l'intérieur de São Paulo. Girotto (1999), Prandi (2001) et Fonseca (2003) sur la religion africaine et afrobrésilienne serviront de base à l'analyse. ceux de Ford (1999) au regard du mythe africain; ceux de Mata (2001) et de Rosario (2001), en ce qui concerne l'origine africaine; et celles de Paiva (2009) et Ferreira (2019) avec leurs contributions sur la danse africaine et afro-brésilienne. Les études de Jenny (1979) et Hutcheon (1985) corroboreront celles de l'intertextualité.

Mots-clés: danse contemporain; conte afro-brésilien; Mythe yoruba; intertextualité; identité noire.

\section{DE ORATURA Y DANZA: OXUM EN LA OBRA OMO-OBA: HISTÓRIAS DE PRINCESAS Y EN EL ESPECTÁCULO BRÁFRICA}

Resumén: En este artículo se pretende analizar, a partir del rito, del mito y de la simbología del orixá Oxum, el cuento "Oxum e seus mistérios", insertado en la obra Omo-Oba: histórias de princesas (2009) de la escritora negra Kiusam de Oliveira, y el espectáculo BrÁfrica (2014), contemplado por el edicto de fomento Nelson Seixas de la Secretaria de Cultura de São José do Rio Preto, interior de São Paulo. Para fundamentar los análisis, se tomarán los estudios de Girotto (1999), Prandi (2001) y Fonseca (2003) sobre religión africana y afro-brasileña; los de Ford (1999) en lo que respecta al mito africano; los de Mata (2001) y de Rosario (2001), en lo que se refieren a la oratura africana; y los de Paiva (2009) y de Ferreira (2019) con sus contribuciones acerca de la danza africana y afro-brasileña. Los estudios de Jenny (1979) y de Hutcheon (1985) fundamentarán los de intertextualidad.

Palavras-clave: danza contemporanea; el cuento afro-brasileño; mito yoruba; intertextualidad; identidad negra.

\section{INTRODUÇÃO}


O presente artigo propõe a análise do conto "Oxum e seus mistérios", presente na obra Omo-Oba - Histórias de princesas da escritora Kiusam de Oliveira, e do espetáculo BrÁfrica, à luz do mito da orixá africana iorubá. Para tanto, inicialmente, algumas considerações sobre rito, mito e religião serão feitas e, posteriormente, a descrição das cenas coreográficas, bem como a da narrativa infantil em questão. Por fim, a relação entre as especificidades do mito e de suas simbologias será entrelaçada aos textos literário e coreográfico.

O espetáculo BrÁfrica foi contemplado em 2013 pelo edital Municipal Nelson Seixas de Fomento à Produção Cultural de São José do Rio Preto no interior de São Paulo. Numa perspectiva artística, direcionou-se a uma área do saber ligada à sensibilidade de movimentos coreográficos expressivos e singulares da dança contemporânea. Além de potencializar a movimentação de maneira particular e significativa por meio do corpo, o dançarino, no espetáculo solo em questão, se abriu para a captação, para a transformação e para a exteriorização das sensações advindas da própria experiência corporal e, principalmente, dos conteúdos ritualísticos e míticos da dança dos orixás africanos cultuados no candomblé do Brasil. O espetáculo, portanto, baseou-se na simbologia da dança de divindades iorubás cuja movimentação é motivada pela idiossincrasia dos mitos.

Já a obra literária Omo-Oba - Histórias de princesas da escritora Kiusam de Oliveira (2009), ilustrada por Josias Marinho, ressalta como princesas se tornam rainhas. O livro possui seis narrativas curtas, dentre as quais "Oxum e seu mistério". De acordo com a própria autora, essas histórias vêm de fontes tradicionais conhecidas, contadas e recontadas pelos iorubás e afro-brasileiros. Assim, como a maioria das histórias antigas de origem oral, quando estas narrativas são contadas, podem ser recontadas e, por isso, reconfiguradas.

A respeito desta importância da oralidade na cultura africana e afro-brasileira, Mata (2001) e Rosário (2001) denominam oratura os conteúdos da tradição oral, considerados como grande acervo em que a memória dos antigos procuram guardar. Conforme os autores, as narrativas orais do universo da oratura relacionam-se com as atividades da vida, vista como todos os sistemas de elementos que concorrem para a sobrevivência da comunidade. Tendo em vista que os mitos africanos são mantidos 
pelos ingorossi banto e itan iorubá nos cultos (orações sagradas), diferente dos grecoromanos que possuem registros escritos nos textos da antiguidade clássica europeia, tal termo torna-se mais pertinente para a análise aqui presente, uma vez que tanto a cena do espetáculo como o do conto infantil retomam a simbologia do mito de Oxum.

A redação do presente artigo que entrelaça mito, dança contemporânea e literatura foi motivada pelo "tripé ideal” de Munanga (2012), na obra Negritude: usos e sentidos, qual seja: o histórico, o linguístico e o psicológico. Ao retomar tais conteúdos, de certa forma, revisita-se a ancestralidade do povo negro, na qual a língua iorubá se faz presente. Além disso, ao se valorizar a cultura africana e afro-brasileira, incentiva-se e destaca-se a riqueza cultural África-Brasil e, assim, solidifica-se a "concretude da autovalorização" do próprio afrodescendente e, consequentemente, daqueles que por este tema se interessam, tendo em vista a proposta da Lei 10.639/03.

O presente artigo, então, conjuga determinados conteúdos culturais dos quais se fazem necessárias considerações iniciais afim de esclarecer e de justificar a proposta de análise. Relacionam-se dança, literatura contemporânea e cultura afro-brasileira por retomarem, em suas expressões poéticas, a divindade Oxum. Por isso, é preciso que se saiba, inicialmente, qual a simbologia desta divindade cultuada na religião candomblé e umbanda.

\section{OXUM IORUBÁ: RITO, MITO E RELIGIÃO}

O candomblé é considerado uma religião reelaborada em função da diáspora africana e conserva traços marcantes da cultura de origem (África), tais como os ritos, a linguagem simbólica, os mitos e os seus valores.

Diferencia-se, conforme Girotto (1999, p. 255), em sua tese intitulada $O$ universo mágico-religioso negro-africano: bantu e nagô, das religiões com contribuições de religiões negras, nas quais “[...] os contritos de origem negro-africanos se apresentam em graus e formas variadas, porém de alguma maneira significativos a ponto de serem identificados por um observador interessado.", como ocorre na Umbanda, no Candomblé de caboclo entre outros, pontua o autor. 
As religiões negras tradicionais em África são coerentes com a ideologia, com o meio e com todos os demais aspectos que constituem a cultura de cada um dos povos, ressalta Girotto (1999). Portanto, em um espaço geográfico diferente, os negros africanos, que foram trazidos ao Brasil, passaram por um processo de ruptura com a terra sacralizada de origem e, consequentemente, com os seus ancestrais.

Vale observar, ainda, que os negros inseridos neste novo espaço geográfico (Brasil) vão sistematizando e modificando "a passos lentos" sua "ideologia", influenciados por novas culturas (europeia - branca; e indígena) e, deste modo, incorporam novos valores. O candomblé surge como sistema reelaborado por reinterpretações das religiões africanas tradicionais; sua estrutura difere de modo bastante significativo daquelas que a originaram, salienta Girotto (1999).

Rodrigues (2010, p. 104), no artigo O candomblé e a cultura afro-brasileira, explica, por exemplo, que:

[...] os africanos fixaram as organizações hierárquicas, a forma religiosa, as concepções estéticas, as relações míticas, a música, os costumes e os ritos, características dos diversos grupos negros. Mesmo com toda a opressão, ainda conseguiram reimplantar os elementos básicos de sua organização simbólica de origem, desenvolvendo formas paralelas de organização social. Por exemplo, caixas de poupança para a compra de alforrias de escravos urbanos, conselhos deliberativos próprios, elaboração de uma síntese representativa do vasto panteão de deuses ou entidades cósmicas africanas (no mínimo 16 orixás) cultuadas, ao contrário da África onde cada cidade-estado cultuava apenas uma divindade, assim como, a preservação do culto aos ancestrais e a continuidade dos modos originais de relacionamento e parentesco, como também a manutenção do iorubá como língua ritualística (RODRIGUE, 2010, p. 104).

Portanto, é por meio de pesquisa social e histórica que se torna possível perceber que tais questões são fundamentais para a concreta valorização da cultura afro-brasileira pelos próprios negros e pelos demais.

Isto remete às considerações Munanga (2012), o qual observa que o grau dessa consciência e valorização seja idêntico entre todos os negros, uma vez que se deve considerar que todos vivem em contextos socioculturais distintos. Para o autor, não é possível confirmar a existência de uma comunidade identitária entre negros que vivem em comunidades religiosas diferenciadas, de terreiros de candomblé, de evangélicos ou de católicos, dentre outras, em comparação com a comunidade negra militante, 


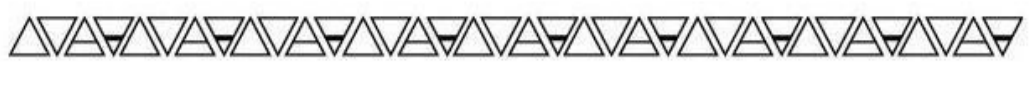

sobremaneira politizada sobre questões como o racismo, ou mesmo com as comunidades remanescentes de quilombos. Para o autor, há diferenças entre estes grupos.

A "identidade perfeita" é vista aqui como aquela que valoriza a cultura e faz com que o negro se identifique e se orgulhe; corresponderia, se levar em conta as elucidações de Munanga (2012), à presença simultânea dos três fatores já citados (histórico, linguístico e psicológico) no grupo ou no indivíduo. Contudo, como se trata de um "caso ideal", há que se optar, de certa forma, por um que se configure como um "elo".

O fator histórico, sob o ponto de vista de Munanga, parece o mais importante, à medida que constitui o "cimento cultural" que une os elementos diversos de um povo por meio do sentimento de continuidade histórica vivido pelo conjunto de sua coletividade. O autor pontua que o essencial para cada povo "é reencontrar o fio condutor que o liga a seu passado ancestral o mais longínquo possível." (MUNANGA, 2012, p. 12).

Conforme as contribuições do autor, é por meio da história, longínqua e ancestral, que o povo esforça-se para conhecer sua verdadeira origem e, assim, transmiti-la às gerações futuras. Convém relembrar que o afastamento e a destruição da consciência histórica foram estratégias usadas no período da escravidão e da colonização para que fosse destruída e mascarada a memória coletiva dos então escravizados e colonizados.

O negro, assumindo-se, "afirma-se cultural, moral, física e psiquicamente. Ele se reivindica com paixão, [...] assumirá a cor negada e verá nela traços de beleza e feiura como qualquer ser humano normal." (MUNANGA, 2012, p. 43). Ao buscar sua identidade cultural, inserida no fator histórico, o negro afasta-se do ódio e do mascaramento étnico, visto aqui como a vergonha e como a desvalorização de seu passado ancestral. Além disso, a negritude resulta na procura do diálogo com outros povos e culturas, já que, como esclarece Munanga (2012, p. 56), “o negro não quer isolar-se do mundo".

Atreladas a estas questões, as novas Diretrizes Curriculares Nacionais para a Educação das Relações Étnico-Raciais e para o Ensino de História e Cultura Afro- 
brasileira e Africana ressaltam a importância de se conhecer a complexidade do processo de construção da identidade negra no Brasil. Esse processo foi e ainda é marcado por uma sociedade que, para desvalorizar os negros, utilizou-se tanto do "apagamento" como do "apequenamento" da cultura de matriz africana e, até mesmo, da desvalorização dos aspectos físicos dos afrodescendentes.

Rodrigues (2010, p. 104), no artigo "O candomblé e a cultura afro-brasileira", chama a atenção para o fato de que, apesar de toda informação a nossa disposição, atualmente, ainda é possível perceber muitas contradições no que se refere à cultura afro-brasileira, devido ao desconhecimento. Por mais que a contribuição dos negros na formação do povo brasileiro tenha sido primordial, ela não é reconhecida, por falta de "conhecimento" de uma parcela. Logo, conhecer-se é um aspecto fundamental para que o negro se valorize e prestigie sua cultura, seu passado e sua história.

Por meio da história, então, o negro (re)visita o seu passado e, assim, se valoriza. Os negros possuem, sim, uma ancestralidade positiva e artística que precisa ser conhecida e divulgada. Deste modo, o resgate, a divulgação, a valorização da história e da cultura africana e afro-brasileira culminam na comemoração feita por meio de movimentos coreográficos expressivos (dança) e da articulação poética da palavra literária (conto) presentes nos textos em análise neste artigo.

Ainda no que diz respeito ao histórico do candomblé, este recebeu uma maior influência das tradições religiosas da região ocidental da África. Dentre as tradições africanas ocidentais, duas, particularmente, marcaram o candomblé: a jejê ou daomeana dos cultos voduns; e a iorubá ou nagô dos cultos dos orixás. O presente artigo prioriza o culto iorubá por conta da natureza da proposta e por conta do culto do orixá Oxum.

O candomblé baseado neste culto foi formado na Bahia, no século XIX, quando o tráfico trouxe do continente africano um número significativo de escravos originários de várias cidades iorubás: Queto, Ijexá, Efã entre outras. Assim, o candomblé, “além de ser uma forma de expressão religiosa, servia igualmente para marcar os espaços das diferentes nações africanas." (MATTOS, 2009, p. 162).

Tendo em vista o processo histórico do tráfico de povos negros escravizados da África para o Brasil, houve entrelaçamentos de etnias que culminaram com a reelaboração dos cultos religiosos, fazendo surgir no Brasil diversos tipos de 


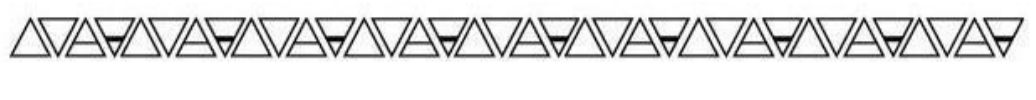

candomblé. Hoje, entre os tipos mais conhecidos, há o candomblé ketu, jeje, angola e de caboclo, conforme os estudos de Cardoso (2006), em A linguagem dos tambores, de Carneiro (1991), em Candomblés na Bahia, e de Parés (2006), em A formação do candomblé.

No que diz respeito aos orixás, são seres sobrenaturais que, conforme o mito e o rito iorubá, orientam o mundo dos vivos e regem as forças da natureza. Reginaldo Prandi (2001, p. 20), em Mitologia dos orixás, explica que, para os iorubás tradicionais e para os seguidores de sua religião nas Américas, "os orixás são divindades que receberam de Olorum ou Olodumere a incumbência de criar e governar o mundo, ficando cada um deles responsável por alguns aspectos da natureza e certas dimensões da vida em sociedade e da condição humana.” A cada orixá é associada uma cor, alguns animais e instrumentos, tais como espada, machado, sabre, cajado, espelho, arco e flecha, chave, pilão etc. De acordo com o mito iorubá, cada orixá possui sua história, seu símbolo e seus ritos.

De acordo com Clyde W. Ford (1999), em O herói com rosto africano - Mitos da África, o panteão iorubá, conhecido como orixás, é significativo não só por ocupar uma posição central desta cultura, mas também porque os orixás sobreviveram nas Américas, constituindo o coração vibrante de práticas espirituais afro-caribenhas e afrosul-americanas e nos Estados Unidos. Embora intimamente atrelada à religião, há, conforme o autor, outra abordagem: “[...] que considera os orixás personificações daquelas energias-arquétipo que se manifestam na natureza e na vida humana: comunicação, guerra, paz, fartura, justiça, beleza, amor, cura, doença, saúde etc.”. (FORD, 1999. p. 207).

No caso do orixá Oxum, ela banha-se, com ternura, nas águas dos rios: penteiase, olha-se no espelho, coloca colares e anéis, ações que estão presentes em sua dança ritualística. De acordo com o Dicionário yorubá português de José Beniste (2014, p. 627), Oxum é "a divindade das águas dos rios que fertilizam o solo e que dá nome a um dos rios que corre na região de Ibadan, na Nigéria”.

Conforme a cosmovisão africana iorubá, no princípio do mundo, Olodumaré mandou todos os orixás para organizarem a terra. Os homens faziam reuniões, mas as mulheres não eram convidadas e, além disso, foram proibidas de participar da 
organização do mundo e, consequentemente, das deliberações. Assim, nos dias e nas horas marcadas, os homens deixavam em casa as mulheres e saiam para tomar as providências indicadas pelo deus supremo.

Inconformadas com a proibição, as mulheres recorreram à Oxum, pois o título de Yalodê já lhe havia sido atribuído: pessoa mais importante entre as mulheres. A divindade, a fim de reverter a situação, foi até ao local em que os homens se reuniam, mas foi impedida de entrar e, portanto, de participar das atividades. Os homens haviam se esquecido de que ela era detentora do poder das águas dos rios, da força dos raios solares e da fertilidade feminina.

Diante desta situação, Oxum tornou os rios inférteis e sem vida, as mulheres tornaram-se estéreis e a força dos raios solares sobre a terra foi aumentada. Não demorou muito tempo para que o povo notasse a mudança que estava ocorrendo e, por isso, os homens consultaram Olodumaré. Ao saber que a orixá não participava das reuniões e das deliberações, o deus supremo exigiu que os homens convidassem Oxum para fazer parte do grupo e os relembrou da importância dos poderes da senhora das águas dos rios para a humanidade.

Vários foram os convites e tentativas dos homens para que Oxum voltasse atrás e participasse da grande reunião. A Yalodê, desta forma, derramou, novamente, as águas pelo mundo; a terra molhada reviveu; as mulheres voltaram a engravidar, e tudo refloresceu. A partir de então, cada vez que terminava uma assembleia, homens e mulheres cantavam e dançavam com muita alegria, comemorando o reencontro e suas possíveis realizações.

Fonseca (2003), no artigo "Filhas do desejo de Eva, herdeiras da sorte de Obá", ao estudar os orixás femininos a partir da perspectiva de Pierre Verger, explica que Oxum representa uma mulher muito bela e sensual, cobre-se de ouro e exala desejo. Entretanto muitas podem ser as faces desta deusa: mãe, guerreira, feiticeira, dócil e vingativa, porém todas enfeixadas em um arquétipo feminino que se alterna entre ser esposa e amante e que fala de beleza, de riqueza e de fecundidade.

Na Nigéria, mais precisamente em Ijesá, Ijebu e Osogbó, corre o rio Oxum, a moradia da considerada a mais bela Iyabá, a rainha de todas as riquezas, a protetora das crianças, a mãe da doçura e da benevolência. 
Generosa e digna, Oxum é a rainha de todos os rios e cachoeiras. Orixá vaidosa, é a mais importante entre as mulheres da cidade, a Yalodê. É responsável pela fecundidade das mulheres e detém grande poder feminino. Oxum é a deusa mais bela e mais sensual, é a própria vaidade; é dengosa, formosa, paciente e bondosa; é a mãe que amamenta e ama, ao mesmo tempo em que seduz e enfeitiça.

Os mitos de Oxum ressaltam a força e a intensidade da sua beleza e de sua determinação para atingir suas metas, seja no amor, na riqueza, na fama ou no prestígio. Seu objeto sagrado é o abebê: espelho que salienta a vaidade e, evidentemente, a preocupação com a beleza. Por isso, gosta de se arrumar com joias, brincos, colares e pentes, e usar perfumes.

Paiva (2009, p. 123), na dissertação $O$ conhecimento incorporado, explica que um dos ritmos mais conhecidos e consagrados deste orixá é o Ijexá. A dança caracteriza-se por um forte apelo à arte de seduzir; os movimentos são contínuos, sem paradas, tal como o movimento das águas dos rios; os gestos são lentos e elegantes, relaxados e ondulatórios; os pés ora movimentam-se para o lado direito, ora para o lado esquerdo e, simultaneamente, os cotovelos abrem-se, girando sobre si mesma. Contudo, o ponto máximo da dança de Oxum é o momento do banho: a divindade africana abaixa-se, pega os enfeites, coloca-os e, ainda, simula o banho, o que pode ser notado com as mãos que, por isso, sugerem o banhar-se nas águas do rio. Ainda abaixada, o corpo dobra-se sobre os joelhos e projeta-se à frente com um fremir das articulações do ombro, como se mergulhasse nas águas de seus domínios. Oxum levanta-se e volta ao movimento inicial com os braços à altura do peito. Logo, o Ijexá remete à simbologia do rito e do mito da divindade.

Para Paiva (2009, p. 125), ao girar sobre si mesma, "Oxum exibe sua beleza e reforça o fato de que é a senhora de todas as belezas". Os movimentos leves e sutis, por sua vez, destacam a personalidade da orixá que utiliza da sua doçura e de seu charme para atrair seus amantes, bem como qualquer coisa de que precise.

O conto "Oxum e seu mistério" e o espetáculo BrÁfrica retomam a narrativa oral africana, poetizando e coreografando-a por meio da literatura e da dança contemporânea. Revisitar o rito e o mito de Oxum exigiu, por meio de diferentes 
linguagens (palavra e movimento), um olhar inovador, no qual a tradição do orixá foi traduzida.

Nesse sentido, cabem aqui as observações de Ford (1999), ao ressaltar que alguns mitos africanos sobreviveram à era da escravidão e passaram a fazer parte do cultura dos afrodescendentes, porém dizem mais respeito à sobrevivência durante aquela época brutal do que a situação atual. A literatura, contudo, destaca Ford (1999, p. 9-10):

[...] não recebe bem a mitologia africana. Os mitologistas ocidentais, inclusive o falecido Joseph Campbell, escrevem pouco e quase sempre com zombaria sobre a mitologia africana, rebaixando as contribuições africanas ao nível das lendas populares, em lugar de colocá-las no patamar das mitologias superiores [...] (Ford, 1999, p. 9-10).

O conto e o espetáculo de dança, pelo contrário, inseriram de forma positiva e reflexiva a dança de Oxum num contexto singular da arte e, por isso, exigem um posicionamento do leitor/espectador que precisa, não apenas, estabelecer relações do passado mítico na atualidade, mas também perceber a releitura realizada neste percurso de ir (passado mítico) e vir (atualidade).

Neste percurso de retorno e de volta à atualidade, os conteúdos, as simbologias e os movimentos simbólicos do orixá ressignificam-se e promovem reflexão, ao mesmo tempo em que valorizam a poética da cosmovisão afro-brasileira. Os textos, desta forma, procuraram reconfigurar a cultura a fim de possibilitar a discussão sobre questões de natureza sócio histórica e cultural.

\section{DESCRIÇÃO DA CENA DE OXUM NO ESPETÁCULO BRÁFRICA}

Antes de o bailarino entrar em cena, há um vídeo projetado no palco de rios e áudio de águas em movimento. Ao término do vídeo, há um rápido silêncio que é quebrado por um som de risos divertidos, de tons que sugerem deboche, êxtase, bem estar e risos seguidos.

Ocorrem mudança de tom e inserção da canção "Au neveau du bar" de Jair Oliveira (compositor e músico brasileiro negro) do CD Simples de 2006. Quando se 
inicia a fala na canção, o bailarino entra em cena: veste-se com saiote cuja base inferior é amarelo ouro; carrega, a tira colo, uma grande bolsa dourada; do outro lado, traz uma grande sacola de compras. O bailarino movimenta-se, aleatoriamente, pelo palco, ao mesmo tempo em que digita em seu tablet dourado e preto.

Em foco no palco, elipsoidal, o bailarino guarda o tablet na sacola e retira da bolsa um banco também dourado. Senta-se. Da bolsa, retira uma garrafa de champanhe; em seguida, da sacola, retira parte do que seria uma taça (a base); junta-a ao bojo também retirado da sacola e concretiza uma ideia: a taça está montada. Após abrir o champanhe, serve-se da garrafa. O bailarino movimenta-se num frenesi, vira-se de perfil, retira parte da cobertura facial feita de meia fina marrom para o primeiro gole. Sempre retirando a cobertura e com chiliques alegres, dá o segundo gole. Na sequência, serve-se novamente e vira a taça completamente.

Ocorre a mudança de áudio: Chopin Romanza Larguetto. Numa transformação, veste-se do sapato dourado meia pata e do vestido, propriamente dito, retirados da grande bolsa. Agora, com nuances clássicos de movimentação, o bailarino move-se inquietantemente aos moldes franceses do ballet clássico com piquer, pat bourrer en changer de côté. Os termos significam pisar, passo cheio e em troca, o qual no ballet clássico consiste no movimento de pisar com troca de pés para direita e para a esquerda, dar giros e realizar outros movimentos.

O bailarino retira da bolsa, à princípio, três laços dourados de diferentes tonalidades amarelas e os coloca, como bordados, no vestido/saiote previamente preparado com velcro a fim de aderência. A movimentação sugere insatisfação, por isso o agora "bailarino-Oxum" coloca a bolsa sobre o banco dourado, enfia a cabeça toda dentro da sacola e, rapidamente, laços são jogados, freneticamente, ao linóleo do palco, seguindo o ritmo crescente da música de Chopin.

Alguns destes laços são aderidos imediatamente; outros posteriormente com muita sutileza. No ensejo final da obra de Chopin, o bailarino, como na coda clássica, desliza pelo palco em ascensão ao final da cena coreográfica. Num repente, a bolsa é retirada do banco, colocada no chão, na qual serão colocadas a garrafa de champanhe e a taça. Como em retrocesso, a bolsa volta à tira colo do bailarino, cujo vestido/saiote já 
está pleno de laços dourados. A sacola, por sua vez, volta ao seu lugar, e o bailarino retira-se de cena antes que o Chopin dê seu último acorde.

Por meio de um processo intertextual, no qual os conteúdos afro-brasileiros são inseridos por meio de movimentos coreográficos, o espetáculo BrÁfrica traz o mito de Oxum e sua dança Ijexá, mas revisitada pela dança contemporânea.

Conceição Evaristo (2019), no Ciclo de Seminários Mulheres nas Artes, ao comentar sobre a intertextualidade na contemporaneidade, no que diz respeito à inserção da cultura negra nas artes, diz que "É sempre uma provocação mesmo; é para marcar um outro lugar; não é inocente. ${ }^{4 "}$

Tendo em vista a pluralidade da linguagem do espetáculo, o som de risos divertidos podem ser relacionados ao bem estar e à riqueza da divindade. As cores amarelas das roupas, do banco, do sapato, da bolsa e do tablete ligam-se ao ouro, elemento de Oxum. A hipérbole do tamanho da bolsa e da sacola singularizam certa ostentação de riqueza do orixá. O tablet, adereço moderno, sugere a fama e os diversos contatos da divindade que é sobremaneira popular, pois trata-se de Yalodê: a mulher mais importante dos iorubás.

Parés (2014, p. 157), no artigo "Xango nas religiões afro-brasileiras: aristocracia e interações sincréticas", explica que:

[...] representações de orixás e voduns são amiúde inspiradas e moldadas por imagens da realeza. No Candomblé, por exemplo, um bom número de orixás, incluindo as iabás (orixás femininos, como Iemanjá, Oyá e Oxum), usam o adê - a coroa real do aláàfin feita com fios de contas. [grifos nossos].

A nobreza apontada por Parés (2014) está presente na releitura do espetáculo BrÁfrica. Vários são os clímax na dança em BrÁfrica nesta cena de Oxum: ao retirar os adereços da grande bolsa, o público surpreende-se. Diferente da dança Ijexá do orixá no candomblé, o "bailarino-Oxum" senta-se no banco dourado como se fosse um pequeno trono e goza o momento ao beber champanhe na taça e ao arrumar-se, assim como o orixá que se banha nas águas do rio e se contempla.

\footnotetext{
${ }^{4}$ Ciclo de Seminários Mulheres nas Artes. Módulo II - Entrevista aberta com Conceição Evaristo. Publicado em 3 de jul de 2019. Em: https://www.youtube.com/watch?v=yy6cTCYe8k4. Acesso em setembro de 2019.
} 
Se na dança no candomblé Oxum movimenta-se com um fremir das articulações do ombro, em BrÁfrica, por outro lado, o bailarino faz movimento frenéticos para exteriorizar a felicidade deste momento de plena exibição ao saborear o primeiro gole. Distinto de Oxum que no ritual usa o adé, espécie de coroa com franjas em pérolas que lhe cobrem o rosto, o bailarino veste uma cobertura na cabeça cor marrom, que impede que os expectadores vejam o seu rosto. Vale ressaltar que o bailarino é afrodescendente.

Os movimentos aleatórios bem como o movimento clássico piquer, pat bourrer en changer de côté no espetáculo de dança contemporânea reforçam a simbologia do luxo e da riqueza presente no mito da orixá e ironizam a cultura clássica, atrelada à dança afro-brasileira que, para os afrodescendentes, é sinal de orgulho e de empoderamento da identidade positiva.

Por fim, assim como no Ijexá, em que Oxum levanta-se do banho, o bailarino guarda os seus pertences, segura a sacola, volta a bolsa a tira colo e se retira da cena.

\section{“OXUM E SEUS MISTÉRIOS" DE KIUSAM DE OLIVEIRA}

Para quem acha que o título do livro de Kiusam de Oliveira é algo simples, engana-se, pois $O M O$ é Filho, criança, descendência, e $O M O Q P B A$ : Filho do Rei, príncipe, princesas. Kiusam de Oliveira (2009), de modo peculiar, chama atenção do leitor no mundo de princesas africanas, baseando-se no mito dos orixás femininos.

O título demonstra a retomada da cultura, do rito e do mito africano iorubá. Ao mesmo tempo em que reproduz e resgata tais oraturas na contemporaneidade, o conto traz desde o título e no seu interior a língua africana. Portanto, trata-se de um texto literário que revisita as africanidades no rito, no mito, na dança e na linguagem.

No conto "Oxum e seus mistérios", a orixá é apresentada e representada dotada de uma beleza e vaidade sem igual, além de ser muito vaidosa:

Oxum era muito linda e perfumada e todos os meninos e meninas desejavam ficar perto dela. Desde criança, Oxum tinha os atributos da beleza, a vaidade, o atrevimento, a genialidade, a determinação e a maturidade. Sabia ser guerreira, mas preferia cuidar de sua beleza: de suas unhas, de seus cabelos, de sua pele e das joias de ouro que só ela possuía. Mas a princesinha Oxum tinha conhecimentos que ninguém mais tinha: ela conseguia hipnotizar com sua 
beleza quem ela quisesse. Suas cores preferidas eram amarelo-ouro e dourado. (Oliveira, 2009, p. 18).

Assim como no mito, a Oxum-personagem encanta por sua beleza e perfume. Com todo esse encanto, também sabe guerrear! Por isso, anda o tempo todo com o espelho na mão esquerda e, na direita, a adaga. Como toda princesa, é coroada com um adé todo em ouro, "com penduricalhos em fios também de ouro, tendo nas pontas ouro no formato de gotinhas de chuva." (OLIVEIRA, 2009, p. 18). Como dito, Oxum no candomblé veste seu adé, ao passo que o bailarino em BrÁfrica veste a cobertura cor marrom que omite o rosto.

No conto, Oxum é amiga de Ogum, detentor da arte de manipular o ferro. Sua responsabilidade, mesmo criança, é a de construir objetos e ferramentas de ferro, em especial as agrícolas. No entanto, cansado de toda essa rotina, Ogum cessa a produção e vai morar sozinho na floresta.

Com o passar do tempo, as ferramentas de ferro construídas pelo orixá Ogum começam a fazer falta na cidade, e o povo, sem instrumentos para o plantio e colheita, começa a passar fome. Com exceção de Xangô, todos os amigos de Ogum tentam, em vão, trazê-lo de volta à cidade, mas são expulsos. Então, todos os homens, reunidos em Assembleia, discutem o que fazer com o menino Ogum na narrativa.

Atrevida como ela só, Oxum-personagem diz que irá à floresta e trará seu amigo Ogum de volta à cidade. Os homens duvidam do sucesso de Oxum, mas a deixam ir.

Oxum vestiu uma saia com cinco lenços pendurados e perfumados que, com o vento, esvoaçavam. Percebe-se no conto de Oliveira (2009), os atributos da orixá africana que se mostra bastante vaidosa e sábia para atingir seus objetivos. A personagem, assim, tirou seu adé, sua coroa, soltou seus lindos cabelos negros e crespos e colocou os pés em contato com a terra; assim, foi em direção ao sítio onde Ogum estava acampado.

$\mathrm{Na}$ narrativa infantil, "Quando a princesa Oxum avistou a cabana de Ogum, fingindo não ter visto nada, começou a dançar com a graça das águas calmas, delicada... suave... num leve vaivém.” (OLIVEIRA, 2009, p. 21), movimento que lembra o Ijexá do candomblé. Seguindo a narrativa, "Dos movimentos que seu corpinho de princesa fazia, um perfume delicioso exalava, e este perfume chegou à cabana de Ogum que saiu 
para ver de onde vinha o perfume. Eis que viu a sua querida Oxum dançando lindamente com o vento." (OLIVEIRA, 2009, p. 21).

Oxum, magicamente, dança e se aproxima do amigo, já hipnotizado. Com um encantamento sobre uma colmeia de abelhas, a orixá pede a elas que derramem seu mel. As abelhas, encantadas com a beleza de Oxum e com a delicadeza de seu pedido, abrem uma fenda na colmeia e o mel, brilhante como o ouro, começa a escorrer nas mãos de Oxum, passando à boca do menino Ogum. Cantava Oxum: "Tome o mel, meu amigo, mas venha para a cidade comigo." (OLIVEIRA, 2009, p. 22).

Ogum acompanhava a dança de Oxum saboreando o mel. Quando deu por si, estava na cidade. Todos aplaudiram o seu retorno e Ogum promete nunca mais abandonar o seu trabalho de ferreiro. Agradeceram a Oxum, que o fez voltar pra lá: “Ora, ie, iê, princesinha Oxum - todos gritavam.” (OLIVEIRA, 2009, p. 22).

$\mathrm{Na}$ história, percebe-se o poder mágico encantador de Oxum que está representado pelos seus atributos, em especial o belo e a dança que caracterizam a divindade, a princesa africana no conto. Com movimentos suaves, no vaivém das águas doces, ela hipnotiza e encanta. Percebe-se a importância da dança no ritual expressos em "Oxum e o seu mistério", como no ritual religioso. Isto porque a dança representa o mito do orixá, a sua força e sua história, como já sinalizado.

De acordo com Connerton (1993), em Como as sociedades recordam, é por meio da natureza corporeizada da existência que se elabora metáforas pelas quais se pensa e se vive: "Quando a princesa Oxum avistou a cabana de Ogum, fingindo não ter visto nada, começou a dançar com a graça das águas calmas, delicada, suave...num vai e vem.” (OLIVEIRA, 2009, p. 21). Já no que diz respeito à dança no espetáculo BrÁfrica, o movimento volta-se à estética que suscita questionamentos no expectador que é motivado a estabelecer relações de sentido entre a dança e o contexto em que tais movimentos estão inseridos.

Para R. Laban (apud ALMEIDA, 2009), a categorização dos movimentos pode ser vista por meio de dois tipos: (i) os funcionais: pentear os cabelos, escovar os dentes, mastigar uma comida, subir escadas ou, até mesmo, escrever na lousa; e (ii) os expressivos, que transmitem uma ideia e uma sensação, como a dor, o prazer, a 
reflexão, o pensamento etc. A dança para o teórico associa-se aos movimentos de natureza expressiva, assim como a poética remete à linguagem da literatura.

Ora, BrÁfrica e "Oxum e seus mistérios" não pretenderam reproduzir a dança de Oxum, mas sim inseriram-na num contexto cênico coreográfico e narrativo poético que possibilitou a percepção dos conteúdos do mito iorubá, bem como toda a simbologia que a ela está ligada. Ao inserir o passado mítico na contemporaneidade, a dança e a literatura realizam um processo de tradução de conteúdos que são reconfigurados e deixam de ser reproduzidos para produzir conteúdos novos.

\section{CONSIDERAÇÕES FINAIS}

Refletir a presença de oraturas (rito e mito) em outros textos (literatura e dança) requer pensar em procedimentos intertextuais. Jenny $(1979$, p. 14) explica que a intertextualidade está ligada à "poeticidade e à evolução literária, pois não ocorre uma simples alusão ou reminiscência, mas sim o aproveitamento de uma unidade textual abstraída do seu contexto.” Neste caso, os ritos e o mito do orixá iorubá estão inseridos num novo sintagma textual, a saber, o espetáculo BrÁfrica e o conto "Oxum e seus mistérios" da obra literária $O M O-Q B A$, história de princesas voltada para crianças e jovens.

A definição de intertextualidade de Hutcheon (1985), neste artigo, não contempla a repetição ridicularizadora, que comumente é vista nas definições dos dicionários populares, mas atende à denominada paródia do século XX, que inclui um paralelismo associado à diferença irônica, um modelo de imitação caracterizado pela distância crítica que nem sempre é constituído na forma de riso. Na concepção da autora, o texto parodiado não visa ao desrespeito e pode até corresponder a uma homenagem.

Neste sentido, BrÁfrica e até mesmo o conto da escritora negra Kiusam de Oliveira "Oxum e seu mistério" conjugam-se ao que Ferreira (2019), no artigo "Corpos moventes em diáspora: dança, identidade e reexistência", chama de "dramaturgia de recordação" a partir de Paul Gilroy (2017). A dança e o conto, por reivindicar a dimensão do coletivo que busca no passado mítico e ritualísticos os laços de parentesco, 
são atualizados como presente positivo e futuro renovador na construção da identidade positiva e, também, "reestruturam modos de pertencimento e existência" (FERREIRA, 2019, p. 9).

Ainda conforme a autora, "Vivemos um ciclo composto majoritariamente de práticas de esquecimento. Recordar é um ato político, quando querem, por exemplo, que simplesmente esqueçamos os números relacionados ao genocídio negro.” (FERREIRA, 2019, p. 9).

Por fim, por meio de linguagens distintas, revive-se o passado ocultado outrora, revisita-se a cultura africana e afro-brasileira e, principalmente, é possível pensá-las articuladas com a arte contemporânea da dança e da literatura, espaços muitas vezes não atribuídos ao fazer e ao poder do povo negro brasileiro.

\section{REFERÊNCIAS BIBLIOGRÁFICAS}

ALMEIDA, Vera Lúcia Paes de. Corpo poético. O movimento expressivo em C.g. Jung e $R$. Laban. São Paulo: Paulus, 2009.

BENISTE, José. Dicionário yorubá-português. Rio de Janeiro: Bertrand Brasil, 2014.

CARDOSO, Ângelo Nonato Natale. A linguagem dos tambores. Tese (Doutorado em Música). Universidade Federal da Bahia, Salvador, 2006.

CARNEIRO, Édison. Candomblés na Bahia. 8. ed. Rio de Janeiro: Civilização Brasileira, 1991.

CONNERTON, Paul. Como as sociedades recordam. Oeiras: Celta Editora, 1993.

FERREIRA, Larissa. Corpos moventes em diáspora: dança, identidade e reexistência. Revista da $A B P N$, v. 11, n. 27 , nov. 2018 - fev 2019, p.50-63.

FONSECA, Denise Pini Rosalem da. Filhas do desejo de Eva, herdeiras da sorte de Obá. ANPUH - XXII - Simpósio de História - João Pessoa, 2003.

FORD, Clyde. O herói com rosto africano. Mitos da África. Tradução Carlos Mendes Rosa. São Paulo: Summus, 1999.

GIROTTO, Ismael. $O$ universo mágico-religioso negro-africano: bantu e nagô. Tese apresentada ao Departamento de Antropologia da FFLCH da USP, 1999.

HUTCHEON, Linda. Uma teoria da paródia. (Trad. Teresa L. Perez). Lisboa: Ed. 70, 1985.

JENNY, Laurent. A estratégia da forma. IN: Poétique: revista de teoria e análise literárias. Intertextualidades. (Trad. C.C. Rocha). Coimbra: Livraria Almedina, 1979.

Revista da ABPN • v. 11, Ed. Especial - Caderno Temático: Cultura popular em cena: artes afro diaspóricas $\bullet$ julho de 2019, p. 7-24 
MATA, Inocência. A oralidade: uma força comunicativa do texto africano - o exemplo da Estória da galinha e do ovo. In: MATA, Inocência. Literatura angolana: silêncios e falas de uma voz inquieta. Lisboa: Mar Além. 2001. p. $142-148$.

MATTOS, Regiane Augusto de. História e cultura afro-brasileira. Ed. São Paulo: Contexto, 2009.

MUNANGA, Kabengele. Negritude: usos e sentidos. Belo Horizonte: Autêntica, 2012.

OLIVEIRA, Kiusam de. Omo-Oba: histórias de princesas. Belo Horizonte: Mazza Edições, 2009.

PAIVA, Kate Lane Costa de. O conhecimento incorporado: aspectos da dança dos orixás no candomblé. Dissertação de mestrado. Instituto das Artes - UERJ - 2009.

PARÉS, Luis Nicolau. Xangô nas religiões afro-brasileiras: "aristocracia" e interações "sincréticas". Revista África(s), v. 1, n. 1, jan/jun. 2014, p. 149-183.

. A formação do candomblé. História e ritual da nação Jeje na Bahia. Campinas: Editora da Unicamp, 2006.

PRANDI, Reginaldo. Mitologia dos orixás. São Paulo: Companhia das Letras, 2001.

RODRIGUES, Neide dos Santos. O candomblé e a cultura afro-brasileira. Revista Tempo, Espaço e Linguagem (TEL), v.1, n.2, maio/agosto 2010, 103-110.

ROSÁRIO, Lourenço do. Contos africanos. Lisboa: Texto Editora, 2001.

Recebido em 30/04/2019

Aprovado em: 30/06/2019 